\title{
MALE PARTHENOGENESIS IN BARLEY
}

\author{
D. ROY DAVIES * \\ Department of Agricultural Botany, University College of Wales, Aberystwyth \\ Received 19.ii. 88
}

LitTLE is known of the role of the cytoplasm in heredity and development. Relevant information has been obtained to a large extent from studies of lower organisms, there being fewer opportunities in higher plants for assessing its importance or for evaluating the interrelations of nucleus and cytoplasm. A greater understanding of the role of cytoplasmic constituents and their organisation, would be of considerable value in elucidating further the nature of gene action and the process of differentiation.

An opportunity of recognising the role of the cytoplasm arose from a study of the anomalous progeny of an interspecific cross of two members of the genus Hordeum. In the course of a series of attempts to overcome the high degree of interspecific incompatibility existing within the genus, (Davies, 1956), a naturally occurring autotetraploid form of Hordeum bulbosum $(2 n=28)$ was crossed with a synthetic autotetraploid form of Hordeum vulgare $(2 n=28)$. From the one hundred and fifty-five flowers of the former species pollinated, seven viable seed were obtained, and three plants survived to maturity.

\section{MORPHOLOGY OF PARENTS AND PROGENY}

$H$. bulbosum is a tall, prolifically tillering form, which, in its early stages of growth, has a prostrate spreading habit. $H$. vulgare on the other hand has fewer tillers, thicker stems, is shorter and more upright (plate, fig. 1). The three progeny are shown in plate, fig. 2 and will be referred to in the text henceforth as Plants I, 2 and 3 respectively, commencing from the left-hand side of the figure.

Plants $I$ and 2 were similar, and both very closely resembled diploid $H$. vulgare. They differed in only one respect-many of the stems branched at the first node below the ear (plate, fig. 3). Plant 3 was also somewhat similar to diploid $H$. vulgare in some, though not all, respects. It flowered very much later, and tillered more profusely, than the latter. It had the characteristic initial prostrate habit, and the dark green leaf colour of $H$. bulbosum. The conformation of some of the ears was also anomalous, in that they had the long awned glumes, and awned lateral florets of $H$. bulbosum. These anomalous ears also invariably exhibited other upsets. Some florets were underdeveloped, others had no ovaries and others had fewer than the normal number of stamens.

* Present address : Isotope Division, Atomic Energy Research Establishment, Wantage Radiation Laboratory, Grove, Wantage, Berks. 
The main features of parents and progeny can be summarised thus :-

\begin{tabular}{|c|c|c|c|c|c|}
\hline \multirow{2}{*}{ Character } & \multirow{2}{*}{$\begin{array}{c}\text { Female } \\
\text { parent } \\
H . \text { bulbosum }\end{array}$} & \multirow{2}{*}{$\begin{array}{c}\text { Male } \\
\text { parent } \\
H . \text { vulgare }\end{array}$} & \multicolumn{3}{|c|}{ Progeny } \\
\hline & & & Plant I & Plant 2 & Plant 3 \\
\hline $\begin{array}{l}\text { Height } \\
\text { Early habit: } \\
\text { Stem thickness } \\
\text { Tiller number } \\
\text { Pubescence } \\
\text { Auricle colour } \\
\text { Mildew resistance } \\
\text { Glume awn length } \\
\text { Lateral florets } \\
\text { Abnormal features }\end{array}$ & $\begin{array}{l}\text { Tall } \\
\text { Prostrate } \\
\text { Thin } \\
\text { High } \\
\text { Pubescent } \\
\text { White } \\
\text { Resistant } \\
\text { Long } \\
\text { Awned } \\
\text { None }\end{array}$ & $\begin{array}{l}\text { Short } \\
\text { Upright } \\
\text { Thick } \\
\text { Low } \\
\text { Glabrous } \\
\text { Red } \\
\text { Susceptible } \\
\text { Short } \\
\text { Blunt } \\
\text { None }\end{array}$ & $\begin{array}{l}\text { Short } \\
\text { Upright } \\
\text { Thick } \\
\text { Low } \\
\text { Glabrous } \\
\text { Red } \\
\text { Susceptible } \\
\text { Short } \\
\text { Blunt } \\
\text { Branching } \\
\text { stems }\end{array}$ & $\begin{array}{l}\text { Short } \\
\text { Upright } \\
\text { Thick } \\
\text { Low } \\
\text { Glabrous } \\
\text { Red } \\
\text { Susceptible } \\
\text { Short } \\
\text { Blunt } \\
\text { Branching } \\
\text { stems }\end{array}$ & $\begin{array}{l}\text { Short } \\
\text { Prostrate } \\
\text { Thick } \\
\text { High } \\
\text { Glabrous } \\
\text { Red } \\
\text { Susceptible } \\
\text { Long in some } \\
\text { ears } \\
\text { Awned in some } \\
\text { ears } \\
\text { Upset in floral } \\
\text { development } \\
\text { of some ears }\end{array}$ \\
\hline
\end{tabular}

\section{CYTOLOGICAL STUDIES}

The two parental forms were autotetraploids $(2 n=28)$. Studies of mitotic configurations in the root tips, and meiotic configurations in the pollen mother cells revealed that the three plants obtained on crossing the two autotetraploids were diploids $(2 n=\mathrm{I} 4)$.

Chromosome pairing was complete in all the progeny (table I). The low chiasma frequency of Plant 3 may have been due to environmental effects, or it may have been another symptom of the developmental upsets that occurred in this plant. Meiosis occurred at the same stage of floral development in the three progeny as in H. vulgare.

Result of hybridisations. Seed setting was complete in all three progeny, on selfing, and on crossing reciprocally with diploid $H$. vulgare. The progeny produced on selfing and crossing were completely normal in all respects, resembling $H$. vulgare and showing none of the anomalies of the original aberrant forms. Their chiasma frequencies at meiosis were as high as in normal diploid $H$. vulgare.

Backcrossing Plants I, 2 and 3 on to the tetraploid $H$. bulbosum did not prove any more successful than crossing diploid $H$. vulgare with tetraploid $H$. bulbosum. 60.54 per cent. of the florets set seed but all embryos died within 28 days of fertilisation, as in the normal cross. No differences in compatibility with $H$. bulbosum existed between the three progeny.

\section{DISCUSSION}

Evidence obtained from the morphological and cytological studies, and the crossing programme indicates that the three plants investigated had arisen as the result of a parthenogenetic development of a diploid 
nucleus from the pollen grain of tetraploid $H$. vulgare. On attempting to cross the latter with $H$. bulbosum, union of the sperm nucleus with the egg was precluded yet presumably the other generative nucleus fused with a nucleus in the embryo sac, as the seeds were well filled, indicating normal endosperm development.

A few examples of male parthenogenesis have been previously recorded-haploid parthenogenesis in Nicotiàna Landsdorffii (Kostoff, I929) and Nicotiana tabacum (Clausen and Lammerts, I929), and diploid parthenogenesis in Fragaria virginiana (Ichyima, 1930) and in Euchlaena mexicana (Collins and Kempton, I916).

In examples of male parthenogenesis, the nuclear material of the progeny is derived from the male parent, and the cytoplasm, it is

TABLE I

\begin{tabular}{|c|c|c|c|c|c|c|c|c|}
\hline \multirow{2}{*}{ Parent } & \multirow{2}{*}{$\begin{array}{l}\text { Chromo- } \\
\text { some } \\
\text { no. }(2 n)\end{array}$} & \multicolumn{4}{|c|}{ Mean metaphase configuration per cell } & \multirow{2}{*}{$\begin{array}{l}\text { Mean no. } \\
\text { of } \\
\text { chiasmata } \\
\text { per cell }\end{array}$} & \multirow{2}{*}{$\begin{array}{c}\text { No. of } \\
\text { cells } \\
\text { analysed }\end{array}$} & \multirow{2}{*}{$\begin{array}{l}\text { Per cent. } \\
\text { pollen } \\
\text { fertility }\end{array}$} \\
\hline & & $\begin{array}{l}\text { Quadri- } \\
\text { valents }\end{array}$ & $\begin{array}{c}\text { Tri- } \\
\text { valents }\end{array}$ & Bivalents & $\begin{array}{l}\text { Uni- } \\
\text { valents }\end{array}$ & & & \\
\hline H. bulbosum . & 28 & $4 \cdot 66$ & $\ldots$ & $4 \cdot 67$ & 0.05 & $26 \cdot 375$ & 120 & $95 \cdot 6$ \\
\hline H. vulgare & 28 & $3 \cdot 087$ & 0.2174 & $7 \cdot 13$ & $0 \cdot 739$ & $23 \cdot 348$ & 23 & $92 \cdot 1$ \\
\hline Plant I & 14 & $\ldots$ & $\ldots$ & 7 & ... & $14 \cdot 166$ & 30 & $96 \cdot 1$ \\
\hline Plant 2 & 14 & ... & ... & 7 & ... & $14 \cdot 203$ & 30 & 94.7 \\
\hline Plant 3 & 14 & ... & .. & 7 & ... & $12 \cdot 6$ & 30 & $97 \cdot 4$ \\
\hline$H$. vulgare & 14 & $\ldots$ & ... & 7 & ... & 14.37 & 24 & $94: 3$ \\
\hline H. bulbosum & 14 & $\cdots$ & $\cdots$ & 7 & $\ldots$ & $12 \cdot 73^{8}$ & 80 & $97 \cdot 2$ \\
\hline
\end{tabular}

assumed, is derived, at least initially, from the female. Hall's work (I954) on increasing the compatibility of species by changing the environment of the maternal plant in the embryo stage, might have led one to expect an increased compatibility of these male parthenogenetic progeny with $H$. bulbosum, but this result was not obtained.

The conclusion of male parthenogenesis must however be reconciled with the abnormal features observed in Plants I, 2 and 3. It is unlikely that they could be attributed to nuclear gene mutation-one would have to assume a very high mutation rate, and the selective elimination of all mutant gametes or zygotes in the second generation, as all the progeny of the aberrant plants were normal. The possibility of chromosome breakage occurring in the embryo sac, followed by a transference of some $H$. bulbosum chromatin to the $H$. vulgare nucleus cannot be ignored, but a similar selective elimination would have to occur here also. Again this latter explanation becomes less plausible when one considers that some of the unusual features of the anomalous plants were not characteristic of the female parent, H. bulbosum.

The most plausible hypothesis regarding the origin of the anomalies or developmental upsets is that they were due to a disharmony of $H$. vulgare nuclear products and the $H$. bulbosum cytoplasmic environment. That the abnormalities were not unduly pronounced, indicates 
that the two species had a very similar biochemical background. The normal development of the artificially cultured triploid hybrid of diploid $H$. vulgare and tetraploid $H$. bulbosum substantiates this conclusion (Davies, loc. cit.).

If the upsets observed could be attributed to nucleo-cytoplasmic disharmonies, then this conclusion must be reconciled with the existence of differences between the three parthenogenetic progeny, and between different parts of a given plant. All the gametes had a similar nuclear constitution and all three plants commenced development in the same ear of $H$. bulbosum and hence had a common cytoplasmic environment.

Differences between and within plants could be attributed to qualitative or quantitative differences in cytoplasmic factors. If these factors are assumed to have been particulate and capable of segregation, the occurrence of aberrations in one part and not another is easily accounted for. Alternatively the differences could have been due to changes in the environment at the time of differentiation, inducing a given state of stable equilibrium in one part, and another state in a second-this latter alternative, however, does not seem too plausible.

If we assume qualitative differences in these particulate cytoplasmic factors, or plasmagenes (Darlington and Mather, I949) we imply the existence of numerous kinds, some of which exerted their influence during the development of ears, others of awns and others of tillers, etc. An alternative explanation could be that of quantitative rather than qualitative differences whereby cells had varying numbers of plasmagenes-an excess of "foreign" plasmagenes from $H$. bulbosum causing an anomaly in the differentiation and development of tissue having $H$. vulgare nuclei.

Quantitative differences in plasmagenes per cell could arise in any of the following ways :

(a) The irregular segregation of "foreign" plasmagenes at cell division. Such an aberrant segregation is thought to be the reason for the production of a respiratory mutant in yeast (Slonimski and Ephrussi, 1949).

(b) A differential survival of "foreign" plasmagenes between cells.

(c) If these cytoplasmic particles could reproduce even in the absence of the nucleus with which they were previously associated, then the non-uniformity within plants could arise from the lack of synchronisation of cell and particle division. This postulate is one that has been developed to account for certain observations of the kappa factor in Paramecium and the carbon-dioxide sensitive factor in Drosophila.

If this last alternative is correct then it is difficult to understand why the "foreign" plasmagenes were not perpetuated in the next generation of plants. They must either have $(a)$ failed to persist through the sporogenous meiotic divisions, or $(b)$ been suppressed prior to gamete formation. 


\section{Plate}

Fig. I.-Autotetraploid Hordeum vulgare on the left, autotetraploid Hordeum bulbosum on the right. $\times$ I $/ \mathbf{I} 0$.

FiG. 2.- The three diploid male parthenogenetic progeny produced on attempting to cross the two plants shown in fig. $\mathrm{I} . \times 1 / 10$.

Fig. 3.-A branching stem typical of two of the male parthenogenetic progeny, and a mormal stem for comparison. $\times 1 / 6$.

Fig. 4.-Spikes and florets of parental forms and of one of the male parthenogenetic progeny (plant 3). $\times 1 / 2$.

A. Hordeum vulgare, with blunt lateral florets and short awned glumes.

B. H. bulbosum, with awned lateral florets, and long awned glumes.

C. Plant 3, with awned lateral florets, and long awned glumes. 

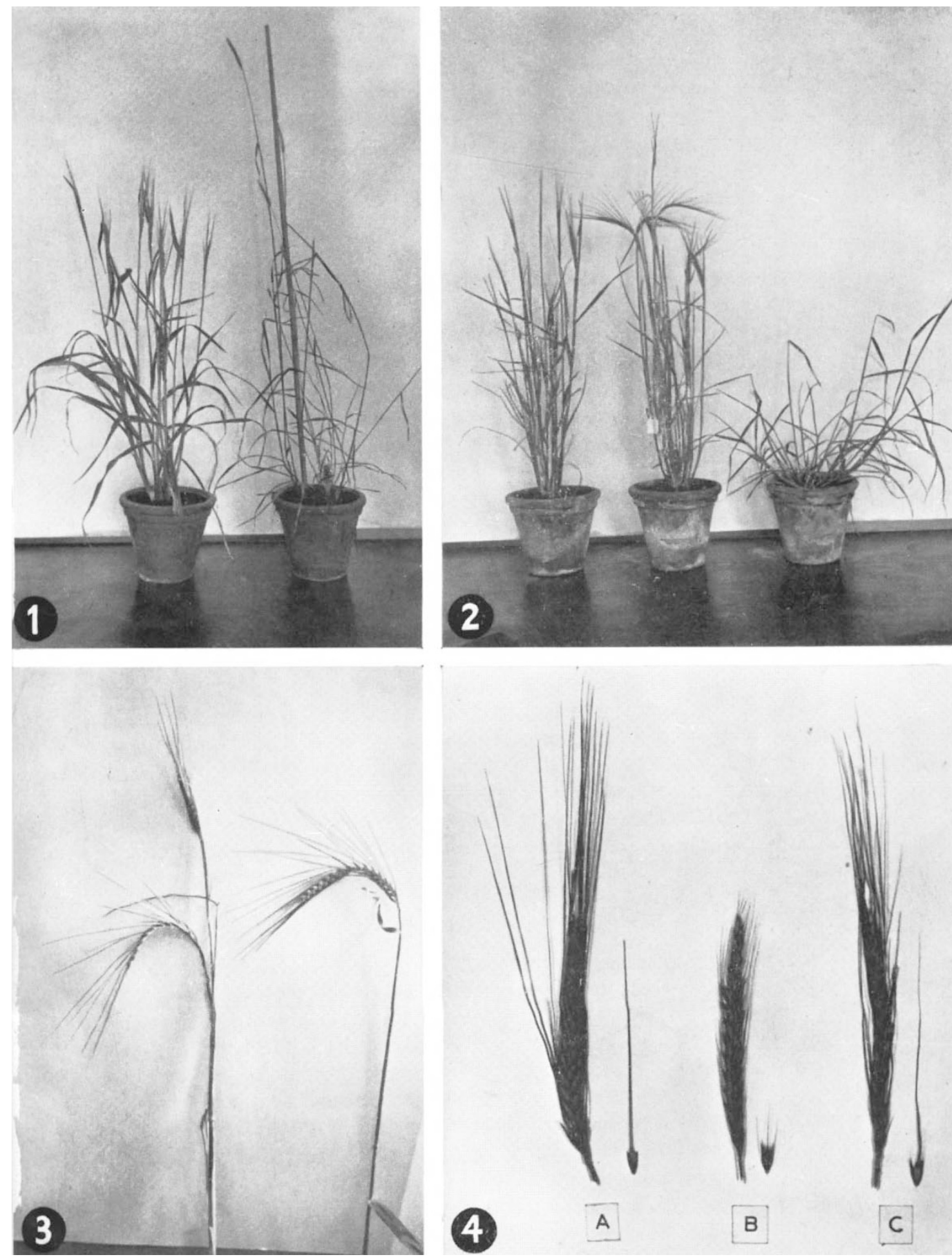
These postulates have assumed the existence of "foreign " plasmagenes, in other words each nucleus is associated with a particular form of plasmagene. Sewall Wright (194I) has suggested how this could arise-inactive plasmagenes exist in the cytoplasm and these become activated by combination with prosthetic groups of nuclear origin. Alternatively a nucleus may act as a selective agent on a population of plasmagenes-favouring the reproduction of one type at the expense of another.

The alternative explanations offered, regarding the cause of the anomalies observed, and the differences between and within plants can be no more than hypotheses-the problem is not open to an experimental elucidation. Observations such as these, however, serve to indicate how the cytoplasm can exert an influence in its own right, but opportunities of recognising this influence occur very rarely. Even in the previously recorded instances of male parthenogenesis it has not been observed. Associations of the nucleus of one species with the cytoplasm of another, have occurred previously-the merogon of Triton palmatus and Triton cristatus being one example. This develops under the control of the maternal cytoplasm for a period of time, but succumbs eventually when the nucleus begins to exert its effect, due to an incompatibility of nuclear products and cytoplasmic constituents. That this did not occur in the present instance could have been due to a fundamental biochemical similarity of the two species concerned, or an early suppression of the incompatible cytoplasmic factors. Little is known of the specificity of any given population of such plasmagenes, and of processes of competition, adaptation, segregation, selection and dominance which may occur between them. As more information accumulates from studies of cytoplasmic inheritance in lower and higher organisms, of the processes of transplantation, grafting, hybridisation and infection, and ultimately the process of differentiation, a further evaluation of the phenomena observed in the present and similar instances will be possible.

\section{SUMMARY}

I. Male parthenogenetic progeny, produced on pollinating autotetraploid Hordeum bulbosum with autotetraploid Hordeum vulgare, were studied morphologically and cytologically.

2. Anomalous features within these plants could not be attributed to nuclear or environmental effects, but were probably due to a disharmony of nuclear and cytoplasmic constituents.

3. An explanation of the differences between and within the plants was sought in terms of quantitative variations of cytoplasmic factors.

Acknowledgments.-This work formed part of an investigation carried out with the aid of a grant from the Agricultural Research Council and under the direction of Professor P. T. Thomas, whose advice and encouragement are gratefully acknowledged. 


\section{REFERENCES}

Glausen, R. E., AND Lammerts, W. E. I929. Interspecific hybridisation in Nicotiana.

$\mathrm{X}$. Haploid and diploid merogony. Amer. Nat., 63, 279-282.

collins, G. N., AND Kempton, I. H. Igi6. Patrogenesis. 7. Hered., 7, ro6-i i8.

Darlington, C. D., AND MATHER, к. I949. The Elements of Genetics. Allen and Unwin Ltd., London.

Davies, D. R. 1956. Cytogenetic studies in wild and cultivated species of Hordeum.

Ph.D. Thesis, Univ. of Wales.

HALL, O. L. I954. Hybridisation of wheat and rye after embryo transplantation.

Hereditas, 40, 453-458.

ICHYiмA, K. I930. Studies of the genetics of Fragaria. Z.I.A.V., 55, 300-347.

коSTOFF, D. 1929. An androgenic Nicotiana haploid. Zeits. f. Zellsfors. m. mikr. Anat., 9, 640-642.

SLONIMSKI, P., AND EPHrussi, B. 1949. Action de l'acriflavine sur les levures. V.

Le systeme des cytochromes des mutants "petite colonie". Ann. de l'Institut

Pasteur, 77, 47-63.

Wright, s. I94I. The physiology of the gene. Physiol. Rev., 21, 487-527. 